\title{
Crack Repair in Concrete Using Biological Methods
}

\section{Zahra Askari ${ }^{1}$, Mehdi Asadi Aghbolaghi ${ }^{2}$, Ali Hasantabar Amiri ${ }^{3}$, Kaveh Ostad-Ali-Askari ${ }^{4 *}$ Saeid Eslamian ${ }^{5}$}

\section{Corresponding author E-mails: \\ Koa.askari@khuisf.ac.ir \\ Kaveh.oaa2000@gmail.com}

${ }^{1}$ Water Engineering Department, Shahre-kord University, Shahre-kord, Iran.

${ }^{2}$ Water Engineering Department, Faculty of Agriculture, Shahrekord University, Shahrekord, Iran.

${ }^{3}$ Department of Civil Engineering, Lenjan Branch, Islamic Azad University, Lenjan,Isfahan, Iran.

${ }^{4 *}$ Department of Civil Engineering, Isfahan (Khorasgan) Branch, Islamic Azad University, Isfahan, Iran.

${ }^{5}$ Department of Water Engineering, Isfahan University of Technology, Isfahan, Iran.

\begin{abstract}
Formation of cracks can be often visible in concrete structures. Although small cracks hardly affect structural properties of a construction, but they increase permeability, which in itself reduces structural stability and threatens structural durability, especially in humid environments. The risk of cracks in concrete structures based in humid environment, such as concrete dams and spillways, is much higher. Concrete repair is a complex process that differs greatly from the recently applied technologies in concrete structures construction. In concrete repair, new materials should be combinedwith old materials in such a way that a suitable combination is obtained able to maintain structures durability over the time against the environmental factors. There are different methods of concrete cracks repair. In the present article we will review several methods for treating concrete cracks.
\end{abstract}

Keywords: Cracks in Concrete, Bacteria, Calcium Carbonate, Biological Method

INTRODUCTION

One of the recent concerns related to concrete structures is concrete cracks and their prevention. Concrete cracks become common, if tensile strength is relatively low. High tensile stresses might be caused by external loads that impose deformation (due to temperature gradients, confined shrinkage,anddifferential settlement), plastic shrinkage and settlement, and expansive reactions (due to gradual reinforcement corrosion, alkali silica reaction, sulfate attack). Without immediate and proper treatment, cracks tend to expand further, and eventually require more expensiverepair of cracks. Durability of concrete is also reduced by these cracks, because cracking creates an easy path for the passage of liquids and gasses that potentially contain harmful substances.

If micro-cracks grow and grow larger, they not only affect the concrete itself, but also the armature becomes attacked when it is exposed towater and oxygen, and possibly carbon dioxide and chlorides, that cause it to corrode [1].In the present article, we will review several methods for the repair of cracks in concrete.

\section{TYPES OF CRACKS IN CONCRETE}

Cracks in Paste: due to water decrease in cement paste.

Early Thermal Cracks: Ambient temperature is one of the important factors affecting emergence of concrete cracks. If concrete was poured in hot weather, it might have caused the temperature of concrete to increase. High temperature causes an increased rate of evaporation of water in concrete, and then, as a result, the hydration process becomes improper and the cracks in concrete are created.

Cracks Caused by Swelling: If concrete, is constantly kept in water, its water absorption will expand, despite the hydration. 
Subsurface Cracks: These cracks are caused by excessive or insufficient trowelling, by putting too much cement in the mixture, and also poor processing.

Shrinkage Cracks: These cracks form and appear as a result of water loss, when the glittering of water disappears from the surface of concrete.

Structural Cracks: These type of cracks are generally linear, and arecaused by the load, thermal stresses or settlement.

\section{REPAIR OF CONCRETE}

\section{Traditional Methods}

Thereareplentydifferentmethodsavailableforrepairofcracks, buttraditional methodshavesomedisadvantageous aspects, such as environmental and health hazards.

\section{Using Fibers}

One of the suitable solutions for concrete cracks repair is to use small quantities of fiber to control the widening of cracks and to increase tensile strength of concrete.The wide application of fibers has begun in the early 1960s in advanced industrial countries, and over the past four decadesthe material and form of fibers, as well as production of fiber-reinforced concrete hasimproved, andits application has increased.The new natural and artificial fibersreplaced straw and cement replaced clay that were traditionally used in cob building material. The fibers used in concrete are made of different materials, such as glass, steel, carbon, polypropylene, Kevlar, etc. Among them, steel fibers have more advantages than other types, including:

1. It has elastic modulus and high strain rate deformation, that,due to the proper formation and high tensile strength, is considered to be one of the most suitable and economical type of fiber.

2. Provides the highest increase in the strength and plasticity of concrete.

3. Various external forms of construction can be made to improve concrete behavior.

4. It is simple to mix it with other concrete materials.

\section{Using Cement Mortar}

By this method the cracks with a width of $1 \mathrm{~mm}$ are filled with plastic material. If cracks are not active, it is possible to use a mortar made of Portland cement or a mortar that hasexpanding properties.However, if the cracks are active, necessarily by taking into account the conditions, sealing with pressuremay also be carried out.

\section{Using Epoxy Resin}

Filling the cracks with epoxy resin injections. By this method narrow ports with a width of $0.05 \mathrm{~mm}$ are put along the cracksat short intervals, and then crackssurface is completely sealed to prevent resin escape and leakage while injecting. If start and end of a crack is not on one heightlevel, the injection should be started from the lowest point until the highest.Transparent tubes are used to ensure optimum filling of injectable material into the cracks.

\section{Using Silica Gel}

Silica gel is used to immobilize bacteria. Silica gel was used not only for bacterial immobilization, but also as a cracks filler before the precipitation of $\mathrm{CaCO}_{3}$. Silica gel is a known microorganisms' immobilizer. Like bacterial cells and yeasts and algae, it creates biological immobilization and is a suitable place for porosity and transfer of molecules and ions [13 and 14]. Polyurethane is also used in addition to bacterial immobilization to seal the cracks [15]. 


\section{Stitching Method}

This method can be used when high tensile strength is required among large cracks. Sewing of cracks leads to stiffening of the structure and that prevents the cracks to transfer to other parts of the structure, therefore it may be necessary to evaluate and to reinforce the surrounding parts as well.

\section{Stressing Method}

If in the parts to be repaired cracks take a wide area and require extensive stitching, the bud method may be considered as a proper solution. By this method the rebar or cables are employed in the damaged area of concrete, and then the pre-calculated stresses are entered onto them, thusfinally stressing them. By using this method care should be taken to ensure that the cracks do not migrate to other areas.

\section{Shotcrete Method}

By this method concrete or mortar is shot using air pressure into the holes, channels, molds, and surfaces to be repaired, but afterwards the surface does not become smooth, it is rough and uneven because of the unequal size of the aggregates used in the sprayed mixture.

\section{Biological Repair}

Since the combined polymers used today to repair and restore concrete are harmful to the environment, the use of biological methods can be very effective.Bacillus bacteria consume nutrients, having calcium lactate, and absorb nitrogen and phosphorus from environment, and thus produce calcium carbonate. Calcium lactate is soluble and calcium carbonate is insoluble. Thus, calcium carbonate precipitates, then hardens and becomes resistant. In addition to this, environment oxygen consumption by bacteria and reduction of oxygen in small crackscauses the reduction of corrosion and decay potential of metal components in concrete. But the presence of bacterial spores and nutrients having calcium lactate are not enough to activate the process of calcium carbonate mineralization.The process begins when hardening concrete removes microscopic cracks and leaking water enters the micro-cracks and reaches bacteria. Under such conditions, the mineralization of calcium carbonate and the self-healing of concrete begins and within a few days to a few weeks micro-cracks will be closed with a calcium carbonate gel precipitation, and a few months later the carbonate gel will harden and concrete will regain its lost resistance.In addition, since the calcium carbonate gel precipitationin the micro-cracks, leaking water cannot penetrate concreteanymore and metal components inconcrete become more resistant, and Bio concrete becomes more lasting.Figure 1 and 2 show the cracks in concrete and a way of how to repair them by producing calcium carbonate.
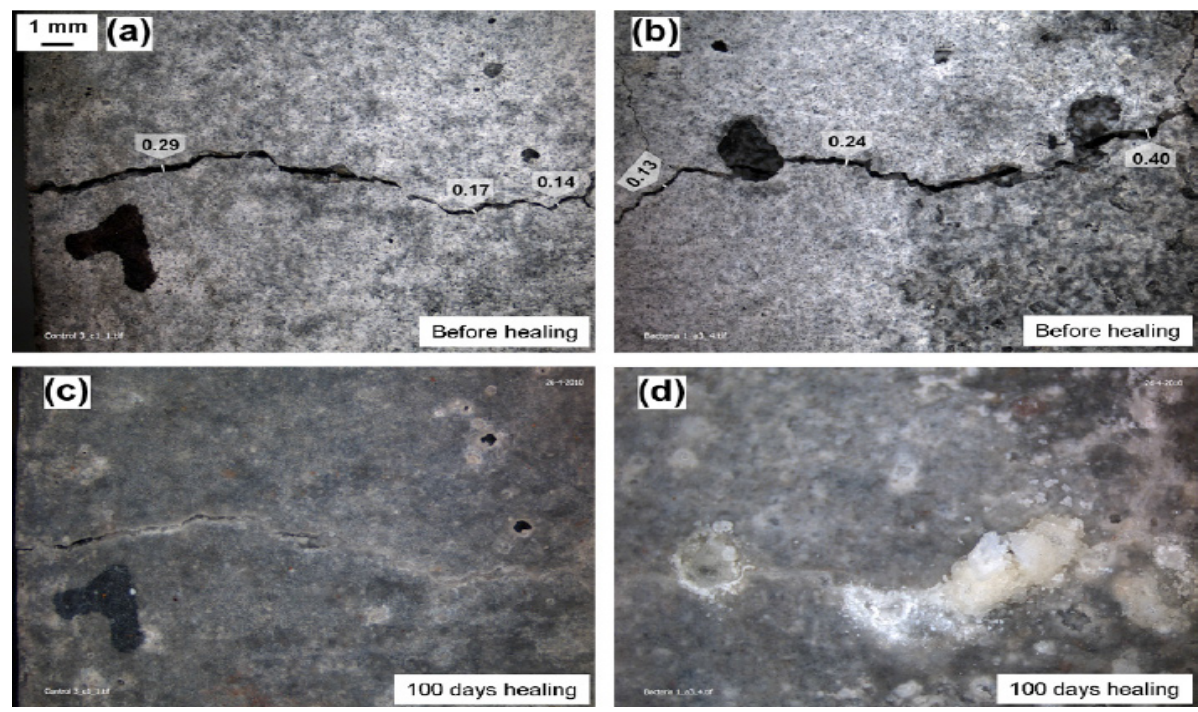

Fig1. Stages of concrete repair by bacteria and calcium carbonate precipitation 

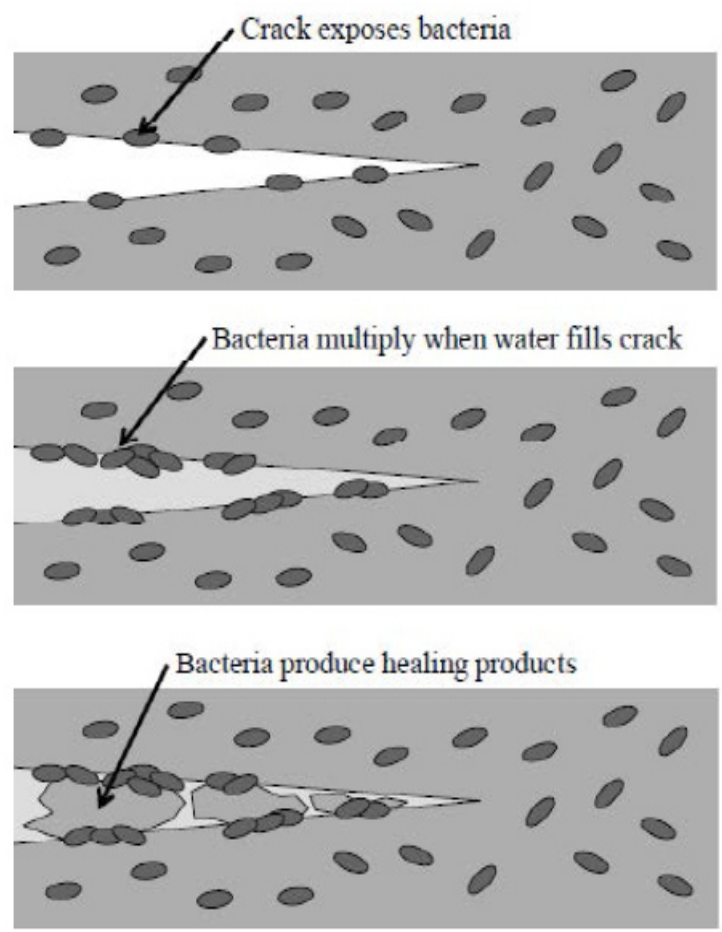

Fig2. Concrete repair by bacteria

Bacterial stimulated calcium carbonate precipitation is a recommended alternative to other cracks repair methods, because it is environment friendly.Types of bacteria,such as Baciluss Sphaericus, Bacillus Cohnii, Bacillus Pasteurii, Bacillus Lentus, Bacillus Sphaericus and Ureolytic, are capable to produce calcium carbonate precipitation.

Varioustypes of biological repair based on different additives in different combinations together with with Bacillus Sphaericus bacteria provide different results that have been compared with traditional methods and cases without repair, and also with different combinations in the graphs below.

$$
\begin{aligned}
& \mathrm{BS}+\mathrm{CaCl}_{2} \rightarrow \mathrm{CaCO}_{3} \downarrow \\
& \mathrm{BS}+\mathrm{CaCl}_{2}+\mathrm{sOl}+\mathrm{gel} \rightarrow \mathrm{CaCO}_{3} \downarrow \\
& \mathrm{BS}, \mathrm{sol}+\mathrm{gel}+\mathrm{CaCl} \rightarrow \mathrm{CaCO}_{3} \downarrow \\
& \mathrm{BS}, \mathrm{sol}+\mathrm{gel}+\mathrm{Ca}\left(\mathrm{NO}_{3}\right)_{2} \rightarrow \mathrm{CaCO}_{3} \downarrow \\
& \mathrm{BS}, \mathrm{sol}+\mathrm{gel}+\mathrm{Ca}\left(\mathrm{CH}_{3} \mathrm{COO}\right)_{2} \rightarrow \mathrm{CaCO}_{3} \downarrow
\end{aligned}
$$

The results of the tests of the above combinationsshowed that, except for repair with the combination $\mathrm{BS}+\mathrm{CaCl}_{2}$ ,in comparison with other cases, all of them show reduced permeability. Repair with $\mathrm{BS}+\mathrm{CaCl}_{2}+\mathrm{sol}+\mathrm{gel}$ and $\mathrm{sol}+\mathrm{gel}$ shows moderate effectiveness and repair with $\mathrm{BS}$, sol $+\mathrm{gel}+\mathrm{CaCl}_{2}, \quad \mathrm{BS}, \mathrm{sol}+\mathrm{gel}+\mathrm{Ca}\left(\mathrm{NO}_{3}\right)_{2}$ and $\mathrm{BS}, \mathrm{sol}+\mathrm{gel}+\mathrm{Ca}\left(\mathrm{CH}_{3} \mathrm{COO}\right)_{2}$ causes lower permeability of water.The resultsare approximately similar to the results of traditional methods and to the results of epoxy use. Also, because chloride may be harmful to concrete, so instead of it, BS combinations can be used with calcium nitrate and calcium acetate as alternative elements. Figures 3, 4 and 5 show the difference between traditional materials and biological materials with the different combinations and their effect on concrete width. 


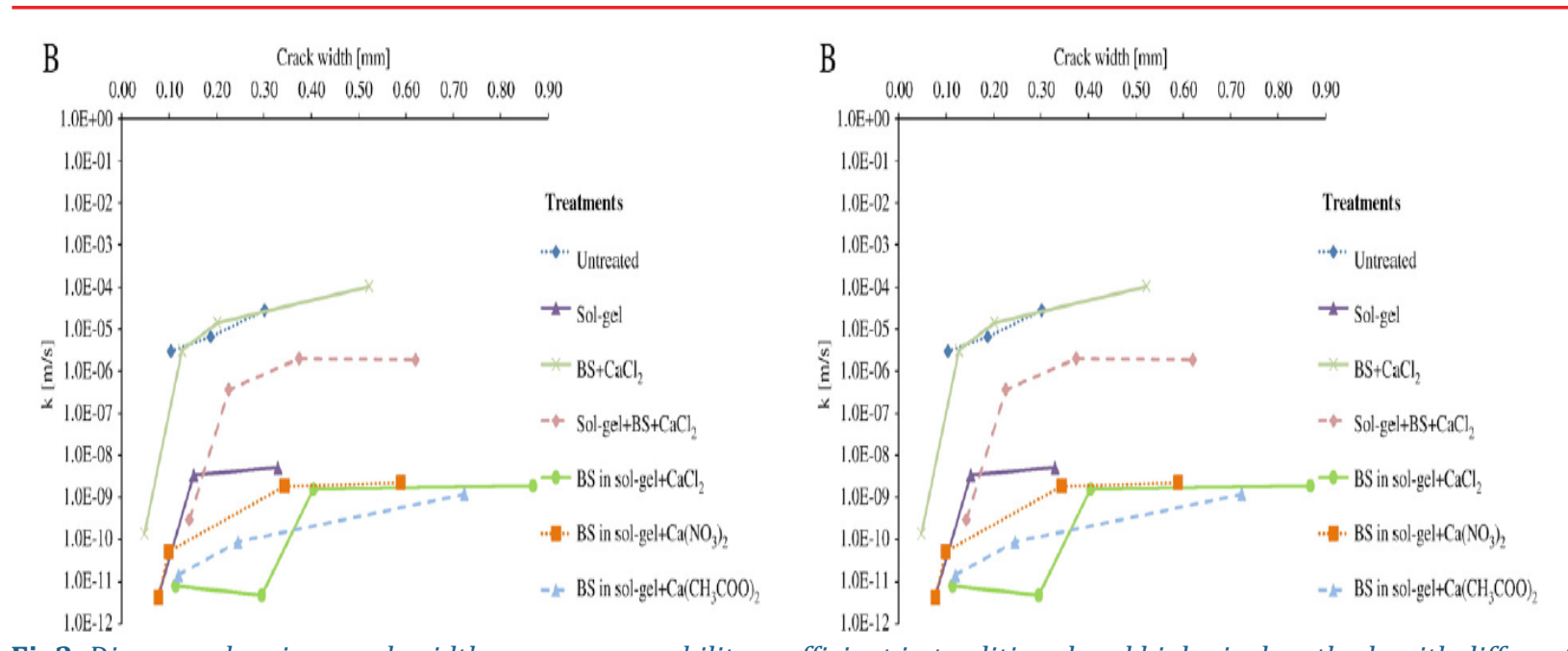

Fig3. Diagram showing crack width versus permeability coefficient in traditional and biological methods with different combinations
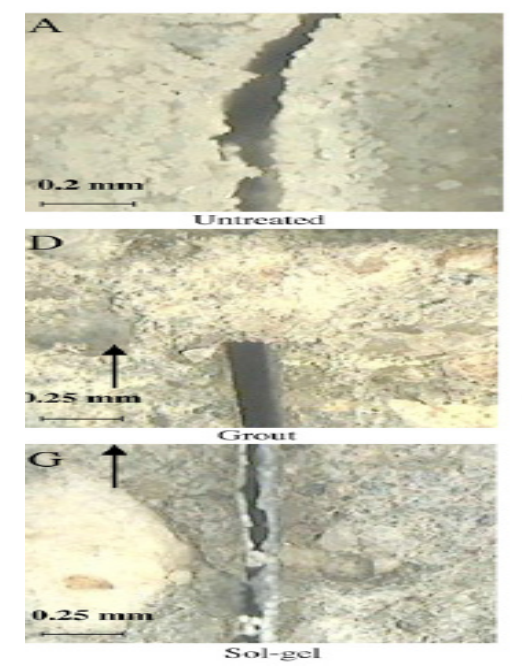

Fig5. Images of BS bacteria repair with different combinations

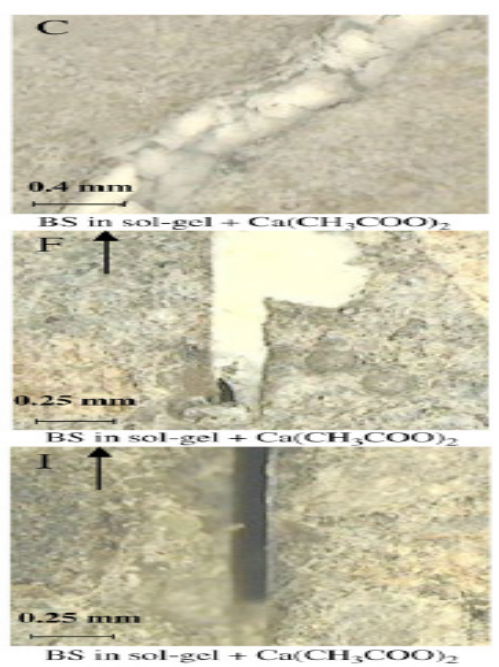

Gollapudi et al. (1995) are the first scientists who introduced the biological method of cracks repair and its compatibility with the environment [2 and 3]. Bacterial precipitation $\mathrm{CaCO}_{3}$ is governed by several factors: concentration dissolved inorganic carbon $\mathrm{pH}$, calcium ions concentration and availability of nucleation sites. The three mentioned factors are created through bacterial metabolism when the cellular membranes of the bacterium operate as a nucleation site [4].The only problem is that the bacterial cells cannot be added directly to the cement samples and, on the other hand, they decrease in the $\mathrm{pH}$ above 12 in concrete.Jonkers et al. showed that bacteria do not survive due to the decrease of cement diameter during hydration [16]. In this method bacteria produce urea, that catalyzes urea hydrolysis $\mathrm{Co}\left(\mathrm{NH}_{2}\right)_{2}$ to ammonium $\left(\mathrm{NH}^{\oplus}{ }_{4}\right)$ and carbonate $\left(\mathrm{CO}_{3}{ }^{-2}\right)$, and the reactions are as follows:

First, onemole of urea is hydrolyzed into an intracellular mole of carbonate and one ammonium mole (Equation 1). Simultaneously, carbonate is hydrolyzed to create another mole of ammonium and carbonic acid (Equation 2). Then creates one mole of bicarbonate and 2 moles of ammonium along with hydroxide ions (Equation 3 and 4). The final reaction happens to increase the $\mathrm{pH}$, which provides the balance of the bicarbonate, and at the end produces carbonate ions (Equation 5). 
(1) $\mathrm{CO}\left(\mathrm{NH}_{2}\right)_{2}+\mathrm{H}_{2} \mathrm{O} \rightarrow \mathrm{NH}_{2} \mathrm{COOH}+\mathrm{NH}_{3}$

(2) $\mathrm{NH}_{2} \mathrm{COOH}+\mathrm{H}_{2} \mathrm{O} \rightarrow \mathrm{NH}_{3}+\mathrm{H}_{2} \mathrm{CO}_{3}$

(3) $\mathrm{H}_{2} \mathrm{O}_{3} \rightarrow \mathrm{HCO}_{3}^{-}+\mathrm{H}^{+}$

(4) $2 \mathrm{NH}_{3}+2 \mathrm{H}_{2} \mathrm{O} \rightarrow 2 \mathrm{NH}_{4}^{+}=2 \mathrm{OH}^{-}$

(5) $\mathrm{HCO}_{3}^{-}+\mathrm{H}^{+}+2 \mathrm{NH}_{4}^{+}+2 \mathrm{OH}^{-} \rightarrow \mathrm{CO}_{3}^{-2}+2 \mathrm{NH}_{4}^{+}+2 \mathrm{H}_{2} \mathrm{O}$

Since the cellular membrane of bacteria has an electronegative nature, the bacteria absorb cations from the environment that contain $\mathrm{Ca}^{+2}$ and precipitate them at the cell surface. Then $\mathrm{Ca}^{+2}$ and $\mathrm{O}_{3}{ }^{-2}$ ions react that causes calcium carbonate precipitation at the cell surface that is saved as nucleation site (equations 6 and 7).

$\mathrm{Ca}^{+2}+$ cell $\rightarrow$ cell $-\mathrm{Ca}^{+2}(6)$

cell $-\mathrm{Ca}_{3}{ }^{-2} \rightarrow$ cell $-\mathrm{CaCO}_{3} \downarrow$

Several bacteria have the ability to precipitate calcium carbonate. These bacteria can be found in soil, sand and natural substances [6]. Jonkers et al. used Bacillus Cohnii bacteria in their studies [6 and 7]. Shanthosh et al. used Bacillus Pasteurii bacteria [8]. Day et al. [9] and Bang et al. [10] also used this type of bacteria. Bang et al. used Bacillus Pasteurii bacteria [11]. Dick et al. also used Bacillus Lentus and Bacillus Sphaericus bacteria [5].

Ureolytic bacteria as well as Bacillus Sphaericus bacteria are capable in their small environment by converting urea into aluminum and carbonate to precipitate $\mathrm{CaCO}_{3}$. The bacterial disintegration, degradation of urea is used to topically increase $\mathrm{pH}$ and boost calcium carbonate precipitation in a calcium-rich places. Subsequently, calcium carbonate precipitation can fill the cracks. Usage of calcium carbonate bacteria precipitation proves its effectiveness. However, when bacteria are used for treatment of cracks in concrete, the very important factor is the high alkaline $\mathrm{pH}$ of concrete, which limits bacterial growth. Therefore, it is necessary to immobilize bacterial cells and to protect them against the high $\mathrm{pH}$ of concrete. Polyurethane, like silica gel, is used extensively as a tool to immobilize enzymes and all cells, due to its physical resistance and biochemical inertia. In some experiments polyurethane was used to immobilize bacteria, but because the process with it is time consuming, instead of polyurethane silica gel was started to be used to immobilize bacteria. Silica gel was used not only for bacterial immobilization, but also as a filler substance of cracks before $\mathrm{CaCO}_{3}$ precipitation. The effectiveness of $\mathrm{CaCO}_{3}$ induced by microbesfor the treatment of cracks in concrete is shownby conducting low pressure water permeability tests, ultrasonic scaling and ultrasonic measurements, and visual inspection of the concrete filling degree.The problem of concrete brittleness can be solved by arming it with steel reinforcement in the direction of tensile strength. But in many cases it is not known exactly where is the direction of tensile strength. On the other hand, in new concrete due to shrinkage, dimensions of concrete are changed and cracks are created that increase permeability, and cause loss of concrete surface, corrosion of reinforcement and reduction of mechanical properties.

\section{CONCLUSIONS}

In this article identification of cracks in concrete and their treatment, that does not require the strengthening and reinforcing of the damaged part, was discussed. If cracks cause certain damage in the structure parts that need to be strengthened, it is necessary to do that. A thorough and accurate analysis and evaluation of the 
structure together withtension control should be performed to provide a suitable reinforcement plan. As it was shown, the biological method of crack repair is a cheap and cost-effective method. The graphs show the permeability effects on the cracks in concrete while using traditional methods and biological method. As can be seen in the graphs, two methods, traditional and biological, have been investigated in terms of crack width and permeability. Graphs show that biological method in small and large cracks reduce permeability and minimize permeability rates at a low cost.

Synthetic polymers are not compatible with the environment and are sensitive to ultraviolet radiation, they also need to be maintained and over time they wear out [ 2 and 3]. Sometimes in some areas repair cannot be done well or is impossible at all. Therefore, the biological method is a simple, inexpensive and environment friendly method, and is more cost-effective than other options.

\section{REFERENCE}

1. N. DeBelie W DeMuynck,(2008). crack repair in concrete using bio deposition, International conference on concreter repair, rehabilitation and retrofifiting.

2. U.K. Gollapudi, C.L. Knutson, S.S. Bang, M.R. Islam (1995). A new method for controlling leaching through permeable channels, chemosphere 30 pp 695-705.

3. S.S. Bang, V. Ramakrishna, (2001). Microbiologically-enhanced crack remediation(MCER) the international Symposium on Industrial Application of Microbial Genomes, Taegu. Korea.

4. F.Hammes, W.Verstraete,(2002). Key roles of PH and calcium metabolism in microbial carbonate precipitation, Reviews in environmental science and biotechnology.

5. J.Dick,W.Windt,B.Graf,H.Saveyn,P.Meeren,N.De Belie. W.verstraete,(2006). Bio deposition of a calcium carbonate layer on degraded lilestone by Bacillus species, Biodegradation pp 357-367.

6. H.M. Jonkers, A. Thijssen, E. Schlangen, (2008) Ontwikkeling van zelfherstellend beton met behulp van bacteren pp78-81.

7. H.M. Jonkers, A. Thijssen, O. Copuroglu, E. Schlangen, (2008). Application of bacteria as self-heading agent for the development of sustainable concrete, Proceedings of the 1 st International Conference on BioGeoCivil Engineering.

8. K. Santhosh, S. K Ramachandran, V.Ramakrishnan, S.S. Bang, (2001) Remediation of concrete using microorganism, American Concrete Ins

9. J.L. Day, V. Ramakrishnan,S.S. Bang,(2003) .Microbiologically induced for concrete crack remediation, 16th Engineering Mechanics Conference.

10. S.S. Bang, J.K. Galiant, V. Ramakrishna (2001). Calcite precipitation induced by polyurethane-immobilized Bacillus pasteurii,Enzyme and Microbial Technology.

11. V. Ramakrishna, R.K.Panchalan, S.S. Bang(2005). Improvement of concrete durability by bacterial mineral precipitation, Proceeding of 11th International conference.

12. K.L. Bachmeier, A.E. Williams, J.R.Warmington, S.S.Bang(2002). Urease activity in microbiologically-induced calcite precipitation, Journal of Biotechnology. 
Crack Repair in Concrete Using Biological Methods

13. U. Soltmann, J. Raff, S.Selena-Pobell (2003)."Biosorption of heavy by sol-gel, immobilized Bacillus Sphaericus cells, spores and s-layers

14. U. Soltman,H. Bottcher, "Utilization of sol-gel ceramics for the immobilization of living microorganisms.pp 66-72.

15. S.S. Bang, J.K. Ramakrishna. (2001). calcite precipitation induced by polyurethane-immobilized Bacillus pasteurii".pp 404-9.

16. H.M. Jonkers, G. Thijssen,O. Copuroglu,E. Schlangen.(2010)application of bacteria as self-healing agent for the development of sustainable concrete

Citation: Zahra Askari, Mehdi Asadi Aghbolaghi, Ali Hasantabar Amiri, Kaveh Ostad-Ali-Askari, Saeid Eslamian, "Crack Repair in Concrete Using Biological Methods", American Research Journal of Civil and Structural Engineering, vol 1, no. 1, pp. 28-35.

Copyright (C) Zahra Askari, Mehdi Asadi Aghbolaghi, Ali Hasantabar Amiri, Kaveh Ostad-Ali-Askari, Saeid Eslamian, This is an open access article distributed under the Creative Commons Attribution License, which permits unrestricted use, distribution, and reproduction in any medium, provided the original work is properly cited. 